\title{
A Head and Neck Surgeon's Consideration of King Hyojong's Poisoning: Fatal Facial Abscess
}

\author{
Han Su Kim \\ Department of Otorhinolaryngology-Head and Neck Surgery, School of Medicine, Ewha Womans University, Seoul, Korea
}

사망에 이른 안면부 심부감염증: 효종(孝宗) 독살설에 대한 두경부외과의사의 의사학(醫史學)적 고찰

김한수

이화여자대학교 의과대학 이비인후과학교실

Received August 4, 2019

Accepted October 11, 2019 Address for correspondence Han Su Kim, MD

Department of OtorhinolaryngologyHead and Neck Surgery,

School of Medicine, Ewha Womans University, 1071 Ahnyangcheon-ro, Yangcheon-gu, Seoul 07985, Korea

Tel $+82-2-2650-2686$

Fax $+82-2-2648-5604$

E-mail sevent@ewha.ac.kr
Background and Objectives The King Hyojong was the 17th King of the Chosun dynasty from 1649 to 1659 . He is well known for his plan for northern campaigns against the Manchus (Bukbeol, 북벌), an act of vengeance on the Qing dynasty for the war of 1636. His plan for the northern conquest was never put into action since he suddenly died of small boil on face in 40 years old. After his death, the reason of his sudden death was questioned by the public. Many people suspected him of being killed by poison. We studied and considered the cause of King Hyojong's death based on two tremendous Chosun dynasty's official records.

Materials and Method We reviewed Joseon Wangjo Sillok (the annals of the Joseon dynasty) and Seungjeongwon Ilgi (the diaries of royal secretariat of the Joeson dynasty).

Results King Hyojong had congenital pre-auricular fistula. He also had been suffering from diabetes and its related complications for a long time before his death. His pre-auricular fistula was infected and not managed properly. It could be presumed that King Hyojong's cause of death was hypovolemic shock from fatal injury of superficial temporal artery caused by inappropriate incision and drainage.

Conclusion We assumed a historical person's cause of death based on Chosun dynasty's official records.

Korean J Otorhinolaryngol-Head Neck Surg 2020;63(10):463-70

\section{서 론}

역사적으로 유명한 인물의 사인에 대해 후세에 연구를 하 는 것은 쉽지 않은 일이다. 기록이 없는 경우가 대부분이고 기 록이 있다고 하더라도 현대에서 사용하고 있는 의학 용어와 상당한 차이가 있어 이를 해석하기도 쉽지 않기 때문이다. 우 리나라에는 세계적으로 매우 뛰어난 기록 유산물이 있는데 바로 조선왕조실록과 승정원일기이다.

조선왕조실록(朝鮮王朝實錄)은 조선 태조로부터 철종에

This is an Open Access article distributed under the terms of the Creative Commons Attribution Non-Commercial License (https://creativecommons.org/licenses/by-nc/4.0) which permits unrestricted non-commercial use, distribution, and reproduction in any medium, provided the original work is properly cited.
이르기까지 25대 472년간의 역사를 연월일 순서에 따라 편년 체(編年體)로 기록한 책으로 총 1893권 888책으로 구성되어 있으며 국보 제 151 호로 지정되어 있다.1) 왕을 비롯한 지배층 위주의 기록이지만 자세하고 방대한 기록물로서 조선시대 각 방면의 역사적 사실을 망라하고 있어 조선시대 역사와 문화 를 연구하는 가장 기본적이 사료로, 1997 년에 훈민정음과 함 께 유네스코 세계문화유산으로 등록되었다. ${ }^{1)}$ 고전 국역 사업 의 일환으로 1968 1993년까지 26년에 걸쳐 신국판(新菊版) 총 413책으로 국문 번역이 완성되었으며, 최근에는 국역 전산 화 작업을 완료하여 국사편찬위원회의 검색 페이지(http://sillok.history.go.kr)에서 자유롭게 열람 및 검색이 가능하다.

승정원일기(承政院日記)는 국보 제303호로 현재의 대통령 
비서실에 해당하는 조선시대 승정원에서 처리한 왕명 출납과 제반 행정 사무, 의례적 사항 등을 기록한 일기로서 조선 초 기의 기록은 임진왜란과 이괄의 난으로 대부분 소실되었고 현재는 1623년(인조 1년) 3월 1910년(융희 4년) 8월까지의 기 록인 3245책이 남아 있다. ${ }^{2}$ 조선왕조실록이 왕의 사후에 작성 된 것이라면 승정원일기는 왕이 생존해 있을 당시 매일매일 을 기록한 문서여서 조선왕조실록에 비해 기록의 양이 훨씬 더 방대하고 1 차 사료로서의 가치가 높다. 승정원일기 또한 국 사편찬위원회의 검색 페이지(http://sjw.history.go.kr/main. $\mathrm{do}$ )에서 열람 및 검색이 가능하나 국문번역 사업이 완성되지 않아 한문 원문을 해독해야 하는 난제가 있다.

\section{재료 및 방법}

조선왕조실록과 승정원일기를 바탕으로 한 조선 왕의 사인 에 대한 연구는 한의학 분야에서는 몇몇이 보고되고 있으나 의학 분야에서는 전무한 편이다. 이에 본 연구에서는 조선의 제 17대 왕인 효종의 사인에 대하여 두 역사적인 기록물 및 후세의 각종 이차 사료를 분석하고 이를 현대의학적 병인론에 기초하여 이비인후과 의사의 관점에서 고찰해 보고자 한다.

\section{결 과}

\section{효종(孝宗)은 누구인가?}

효종(孝宗)(1619 1659년)은 조선의 제 17대 왕(재위 1649 1659년)으로 병자호란 당시 형인 소현세자와 함께 청나라에 볼모로 잡혀가 8년간 있었다. ${ }^{3)}$ 소현세자는 청나라에서 볼모 생활을 하는 동안 서양인을 포함한 각계각층의 인물과의 교 류와 선진 문물을 접하게 되면서, 현실적으로 청의 강대함을 인정하고 청과의 관계 개선 및 외부 문물의 유입을 통해 조선 을 개혁하고자 하는 생각을 가지게 되었다. 1645 년 긴 볼모 생 활을 끝내고 귀국한 소현세자는 자신의 꿈을 펼치지도 못한 채 반청주의자인 부왕 인조와 지속적인 갈등을 빚던 중 귀국 2 달 만에 급사하게 된다. ${ }^{4)}$ 이에 청나라에 머물고 있던 동생인 봉림대군이 귀국하여 소현세자의 아들인 석철을 대신하여 왕세자로 책봉되고 인조 사후에 즉위하니 이가 바로 효종이 다. 효종은 즉위 후부터 형인 소현세자와는 달리 병자호란의 치욕을 갚는다는 명분하에 재위 10 년 동안 강력한 북벌(北伐) 정책을 펼쳤다. 북벌론은 형인 소현세자를 대신해 차자(-欠欠子) 로서 왕이 된 효종이, 정통성을 확보하기 위해 전란이 끝난 지 얼마 되지도 않은 시점에서 백성들의 고통을 오히려 더 가중시키는 명분론에 기반한 비현실적인 정책이라는 비판이 있으나, 두 번의 전란으로 무너져버린 민족의 자긍심을 고취
시키기 위한 노력이었다는 다양한 평가도 있다. ${ }^{5)}$ 그러나 북벌 론은 실행에 있어서 당시 집권 세력이던 송시열을 필두로 하 는 사대부의 강력한 반발에 부딪쳤다. 양측 모두 북벌이라는 명분에는 동의했으나 효종이 군사력 증강을 기반으로 하는 숭무 정책을 통해서 물리적이고 실제적인 북벌을 계획한 반 면 서인으로 대표되는 사대부들은 주자학의 틀 안에서 철학 적 의미에서 청에 대한 우위를 강조하는 한편, 다양한 현실적 인 이유를 들어 북벌의 실행에 미온적이었다.) 효종은 이에 기존의 관행을 무시한 채 사관의 대동 없이 서인의 거두인 송 시열과 단 둘만이 만나는 일종의 담판(기해독대, ᄅ亥獨對)을 통해 사대부를 압박하고 북벌의 실행을 촉구하였으나, 약 두 달 후 머리에 난 종기를 치료하던 중 갑자기 급사하게 되어 북벌론은 역사의 뒤안길로 사라지게 된다. 현재의 다양한 평 가가 어떠하든 북벌에 대한 강한 의지를 가졌던 40 세의 젊은 군주의 갑작스러운 죽음은 사후 정치적 상황과 어우러져, 사 망을 둘러싼 끊임없는 의혹과 함께 독살설이 제기되었곡) 다 양한 소설과 드라마의 소재로 다루어지고 있다.

\section{효종 사망의 주요 쟁점}

조선왕조실록에서 효종의 증상에 대해서 처음 기술한 1659 년 4월 27일(음력. 이후 모든 날짜는 기록 당시에 사용한 음력 을 따름)부터 사망 당일인 5월 4일까지의 기록 중 효종의 질 병 및 사망과 관계된 기록은 Table 1과 같다. ${ }^{8)}$ 이 내용을 토대 로 효종 독살설이 제기되었는데 그 주요 쟁점은 다음과 같다. 1) 병변이 머리 위의 작은 종기에 불과함, 2) 증상 발생부터 사 망까지 이른 시간이 7 8일로 급성 경과를 보임, 3) 사망 당시 효종은 40세로 건강한 상태였음, 4) 침(鍼)에 의한 손상으로 과다출혈이 발생하기 쉽지 않고 침을 놓은 신가귀가 당시 수 전증을 않고 있었음 등이다. ${ }^{67)}$ 이에 각 쟁점에 대해서 조선왕 조실록, 승정원일기 등 1 차 사료와 기타 2차 사료를 포함하는 문헌을 현대의학적 관점에서의 고찰을 통해 효종 사망의 원 인을 찾아보았다.

\section{종기는 무엇이며 종기의 발생 부위는 어디인가?}

효종실록 21권, 효종 10년 4월 27일 정사에 의하면 첫 증상 을 다음과 같이 기술하고 있다(Table 1). "상이 머리 위에 작은 종기를 않고 있었으므로 약방(藥房)이 들어와 진찰한 다음 약을 의논하여 올렸다(上患䰎髮上小腫, 藥房入診, 議藥以 進)."9) 국문 번역본을 읽어 보면 그다지 대수롭지 않은 작은 종기가 머리 위에 생긴 것으로 생각할 수 있다. 그러나 한문 본문을 보면 조금 더 자세한 발생 부위를 알 수 있다. /䰎/은 '살쩍 빈'으로 살쩍, 즉 관자놀이와 귀 사이에 난 머리털을 뜻 하고, /髮/은 '터럭 발’로 역시 몸에 난 길고 굵은 털 또는 머 
리털을 뜻하는 말이다. 승정원일기 156책(탈초본 8책) 효종 10 년 4월 27일 기록에는 발생 부위에 대한 설명이 좀 더 자 세한데, 오른쪽(右) 빈발(鬢髮)의 가장자리(邊)의 위에(之上) 종기가 발생했다고 기술하고 있다(自上右邊䰎髮之上). ${ }^{10}$ 즉 종기의 발생 부위는 ‘머리 위’라는 애매모호한 부위에서 우측 구레나룻 부위로 한정이 가능해진다.
그럼 종기는 무엇이었을까? 조선왕조실록에서는 작은 종기 (小腫)가 생겼다고 기록되어 있고" 승정원일기에서는 작은 부 스럼(有小痕)이 발생하였다고 기록되어 있다. ${ }^{10)}$ 승정원일기에 서 사용한 /㾿/은 '부스럼 절로 부스럼을 일컬을 때 사용하기 도 하지만 목 부분의 결핵성 만성 종창을 지칭할 때도 사용 하는 글자로서 揤瘍(절양)은 살갖에만 나는 화종성 염증 또

Table 1. 효종의 병세 및 사망 과정에 대해 조선왕조실록에 기록된 내용

상이 머리 위에 작은 종기를 않고 있었으므로 약방(藥房)이 들어와 진찰한 다음 약을 의논하여 올렸다. 이때 왕세자도 병을 않았는데 증세가 매우 중하였으므로 상이 이를 걱정하느라고 종기 않는 것에 마음을 쓰지 않았었다. 그리고 전정(殿庭)에 나아가 서서 직접 비를 빌다가 상처가 더 악화되 어 종기의 증세가 점차 위태롭게 된 것이다. 그래서 이날에야 비로소 약방에 하교한 것이다.

\begin{tabular}{lc}
\hline & 효종 10년 4월 28일 (2일) \\
\hline 약방이 들어와서 진찰하였는데, 종기의 독이 얼굴에 두루 퍼져 눈을 뜰 수가 없었다. \\
\hline 효종 10년 4월 29일 (3일) \\
\hline 약방이 들어와서 진찰하고 나서 약을 의논하여 올렸다. \\
\hline
\end{tabular}

약방 제조(藥房提調)가 약방에서 숙직하였다. 이때 상의 종기 증후가 점점 위독하여지자 제조 홍명하(洪命夏)가 말하기를, “시약청(侍藥廳)을 설치 하지 않을 수 없다." 하고 도제조 원두표(元斗杓)는 말하기를, "지금 시약청을 설치하자고 청하면 상의 마음이 반드시 놀라게 될 것이고 뭇사람들도 의혹스럽게 여길 것이니, 경솔히 의논해서는 안 된다.” 하였다. 때문에 외정(外廷)의 신하들은 모두 상의 증후의 경중이 어떠한지를 알 수가 없었다. 효종 10년 5월 1일 (5일)

약방이 문안하니, 답하였다. "종기의 증후가 날로 심해가는 것이 이와 같은데도 의원(醫員)들은 그저 심상한 처방만 일삼고 있는데 경들은 심상하게 여기지 말라.”

약방이 들어가 진찰하니, 부기(浮氣)가 점점 심하였다. 의관(醫官) 유후성(柳後聖)이 아뢰기를, "독기(毒氣)가 안포(眼胞)에 모여 있으니 의당 산침 (散鍼)을 놓아서 배설시켜야 합니다.” 하니, 따랐다.

저녁에 또 산침을 맞았다. 효종 10년 5월 2일 (6일)

약방이 들어가 진찰하였다. 효종 10년 5월 3일 (7일)

상의 병이 위독하여 편전(便殿)에 나아갈 수 없었다. 약방이 대조전(大造殿)에 들어가 진찰하였다. 상이 산침을 맞았다. 저녁에 약방이 또 들어와 진찰하였다. 상이 입시한 의관들에게 진맥해 보라고 명한 뒤에 인하여 종기 증후의 경중을 하문하였다. 의관들이 감히 분명히 말하지 못하니, 물러 가라고 명하였다.

효종 10년 5월 4일 (8일)

상이 대조전에서 승하하였다. 약방 도제조 원두표(元斗杓), 제조 홍명하(洪命夏), 도승지 조형(趙珩) 등이 대조전의 영외(䘤外)에 입시하고 의관 유 후성(柳後聖) - 신가귀(申可貴) 등은 【이때 신가귀는 병으로 집에 있었는데 이날 병을 무릅쓰고 궐문(關門) 밖에 나아가니, 드디어 입시하라고 명하 였다.】먼저 탑전에 나아가 있었다. 상이 침을 맞는 것의 여부를 신가귀에게 하문하니 가귀가 대답하기를,

“종기의 독이 얼굴로 흘러내리면서 또한 농증(膿症)을 이루려 하고 있으니 반드시 침을 놓아 나쁜 피를 뽑아낸 연후에야 효과를 거둘 수 있습니다.”

하고, 유후성은 경솔하게 침을 놓아서는 안 된다고 하였다. 왕세자가 수라를 들고 난 뒤에 다시 침을 맞을 것을 의논하자고 극력 청하였으나 상이 물리쳤다. 신가귀에게 침을 잡으라고 명하고 이어 제조 한 사람을 입시하게 하라고 하니, 도제조 원두표가 먼저 전내(殿內)로 들어가고 제조 홍명 하, 도승지 조형이 뒤따라 곧바로 들어갔다. 상이 침을 맞고 나서 침구멍으로 피가 나오니 상이 이르기를,

“가귀가 아니었더라면 병이 위태로울 뼌하였다.” 하였다.

피가 계속 그치지 않고 솟아 나왔는데 이는 침이 혈락(血絡)을 범했기 때문이었다. 제조 이하에게 물러나가라고 명하고 나서 빨리 피를 멈추게 하는 약을 바르게 하였는데도 피가 그치지 않으니, 제조와 의관들이 어찌할 바를 몰랐다. 상의 증후가 점점 위급한 상황으로 치달으니, 약방에서 청심원 (淸心元)과 독삼탕(獨參湯)을 올렸다. 백관들은 놀라서 황급하게 모두 합문(閤門) 밖에 모였는데, 이윽고 상이 삼공(三公)과 송시열(宋時烈) · 송준 길(宋浚吉), 약방 제조를 부르라고 명하였다. 승지 - 사관(史官)과 제신(諸臣)들도 뒤따라 들어가 어상(御床) 아래 부복하였는데, 상은 이미 승하하 였고 왕세자가 영외(榲外)에서 가슴을 치며 통곡하였다. 승하한 시간은 사시(巳時)에서 오시(午時) 사이였다. 
는 피부가 불결하여 생기는 털주머니의 구멍, 또는 피지선에 화농균이 들어가 발생하는 종창을 뜻하기도 한다. ${ }^{11}$ 즉 효종 의 병세는 단순히 피부에 발생한 간단한 종기로도 볼 수 있 지만, 세균성 감염에 의해 발생한 비교적 크기가 큰 화농성 병변으로도 생각할 수 있다.

효종이 사망하기 3년 전인 효종 7년 10월 7일에 기록된 승 정원일기를 보면 효종의 우측 귀를 진찰한 의관이 “始伏審右 耳有浮氣(㾕痛之症”라고 기록하였다. ${ }^{12)}$ 번역을 해보면 “이제야 엎드려서 자세히 살펴보니(始伏審) 오른쪽 귀에(右耳) 부기가 있으며(有浮氣) 가려운 통증의 증상이 있습니다(棒痛之症). 라는 뜻이다. 이후 귀의 증상에 대해 좀 더 자세한 언급이 있 는데 '밤이 될수록 부기가 더욱 심해지며(而去夜則浮氣益高), 게다가 열의 증상이 있고(且有熱候), 귀 구멍은 부어 좁아졌 고(耳孔浮窄), 가려운 통증은 더욱 심해진다(痒痛尤甚)'라고 기술하고 있다. 하루 뒤인 10 월 8일 기사에서 의관은 귀 '앞'의 부기와, 통증의 증상(耳前浮氣痒痛之候)과, 귀 구멍의 협착 (耳孔浮窄)이 어제에 비해 어떠십니까(比昨何如)라고 묻는 데 ${ }^{13)}$ 즉 부기가 발생한 부위가 효종이 사망에 이른 효종 10년 4월 27일 발생한 종기와 동일한 부위인 것을 알 수 있으며 약 7일 정도 지속이 된 것으로 추측된다(答曰, 耳痛之症, 近來平 常; 답하기를 귀의 통증은 근래 들어 평상과 같다.). ${ }^{14}$ 따라서 사망 당시 효종의 머리에 발생한 종기는, 우측 귀 바로 앞 구 레나룻에 발생, 염증 증상(화농성 병변/안면부 부종) 및 이개 협착 등의 증상, 37세 및 40세에 반복적으로 발생 등의 소견 을 종합해 볼 때(Table 2), 전이개누공(pre-auricular fistula) 에 발생한 2차성 감염 및 이에 속발한 안면부 세포염일 것으 로 생각된다. 또한 이 외 새열기형낭종(branchial cleft cyst) 제1형에 발생한 화농성 병변의 가능성도 감별을 해야 할 것 이다.

\section{병은 경증 질환으로 급성 과정이었나?}

증상이 조선왕조실록에 처음 기록된 지 8일 만에 갑자기 사망한 것 또한 독살설을 지지하는 중요한 소견으로 언급이 되고 있다. 그런데 효종 10년 4월 27일의 기록을 보면 "이때

Table 2. 효종 사망 당시 발생한 종기의 양상

\begin{tabular}{ll}
\hline 발생 부위 & 우측 귀 앞쪽 \\
발생 양상 & 반복적 (2회 발생), 일주일 정도 지속 \\
발생 시기 & 1 차: 효종 7년 10월 (37세) \\
& 2 차: 효종 10년 4월 (40세) \\
병변의 증상 & 귀 앞쪽 부위의 부종 및 종기(화농성 병변) \\
& 안면부의 세포염 \\
& 가려움, 외이도 협착 \\
국소 증상 & 발열 등 전신 증상 \\
동반 증상 &
\end{tabular}

왕세자도 병을 않았는데 증세가 매우 중하였으므로 상이 이 를 걱정하느라고 종기 않는 것에 마음을 쓰지 않았었다. 그리 고 전정(殿庭)에 나아가 서서 직접 비를 빌다가 상처가 더 악 화되어 종기의 증세가 점차 위태롭게 된 것이다. 그래서 이날 에야 비로소 약방에 하교한 것이다."라고 기록되어 있다. ${ }^{9}$ 즉 이미 4월 27일 이전에 효종은 증상이 있었지만 왕세자의 병과 기우제 등의 행사를 직접 주제하느라 내의원에 이야기를 하 지 않았던 것이다. 그럼 증상이 시작된 날은 언제일까? 효종 10 년 4월 27일 이전 한 달의 조선왕조실록과 승정원일기를 보면 이에 대한 기록은 없다. 그런데 조선왕조실록의 부록으 로 영돈령부사 이경석(李景䐕)이 쓴 '효종 선무장무 신성현인 대왕 행장'에 보면 '4월 20일 뒤에 병에 감염되었는데도 기우 제를 실행하도록 명하였으나라는 기록이 있으며 ${ }^{15)}$ 송시열(宋 時烈)이 지어 올린 지문(誌文)에는 '그런데 기해년 4월 22일에 병을 앓아 미령한 중에도 오히려 농사의 병통을 안타깝게 여 겨 한데 서설 비를 빌었다가 다음달 5 월 4일에 창덕궁의 정침 에서 승하하니 ${ }^{15)}$ 라고 기록된 것으로 보아 병의 첫 증상이 나 타난 것은 4월 22일로, 사망하기 2주 전으로 추측할 수 있다.

또한 조선왕조실록에 첫 증상이 기록된 4일 뒤인 4월 30일 기록을 보면 내의원의 제조 홍명하가 시약청(侍藥廳) 설치에 대해 상관인 도제조 원두표에게 건의를 하는 기록이 있다 (Table 1). 시약청은 조선시대에 왕 또는 왕실 인물의 병의 상 태가 중태일 때 설치하는 임시 관서로 내의원 소속의 의관뿐 아니라 의학에 능통한 모든 신하들을 참여시키는 치료 기관 으로 ${ }^{16)}$ 현재로 따지면 일종의 다학제 진료에 해당한다고 볼 수 있다. 따라서 효종의 증세는 조선왕조실록에 기록이 시작 된 바로 다음날에 '종기의 독이 얼굴에 두루 퍼져 눈을 뜰 수 없는 상태'까지 악화되었으며 ${ }^{17)}$ 내의원 의관들 또한 시약청 설 치를 고려할 정도로 효종의 상태가 심상치 않음을 인지하고 있었다고 볼 수 있다.

\section{효종은 건강한 상태였나?}

효종의 독살설을 주장하는 측의 논거 중 하나가 효종이 40세의 비교적 젊은 나이에 급사를 한 점을 들고 있다. 40세 는 현재의 시점에서 보면 젊은 나이지만 17세기의 관점에서 보면 그다지 젊은 나이가 아닐 수 있다. 조선 태조(太祖)부터 순종(純宗)에 이르기까지 조선시대 27명의 왕의 평균 수명은 겨우 47.07세로 조선왕조실록에서 생몰연대가 분명한 사대부 1408 명의 평균 수명인 64.7세보다 횔씬 짧다. ${ }^{18)}$ 그렇다면 사망 당시 효종의 건강 상태는 어떠했을까? 김훈의 연구를 보면 효종은 즉위년부터 각종 질환에 시달렸으며 35세 무렵에는 알 수 없는 질환으로 10 개월 정도 투병을 했던 것으로 보인 다.) 또한 말년인 효종 9년과 10년에는 질병 및 치료에 대한 
기록이 빈번하게 승정원일기에 기록되어 있는데 사망 직전인 효종 9년 6 11월까지 약 5개월 동안은 빈번하게 침을 맞고 약 방제조와 의관이 번갈아 가며 숙직까지 하였다는 것을 보면 병세가 상당히 심각했던 것으로 보인다. ${ }^{5)}$

전이개낭종 또는 새열기형낭종에 염증이 발생하고 2차적 으로 화농성 변화가 생겼다고 해도 40세의 건장한 남성이 발 병 1 2주만에 안면부 전체로 염증이 퍼져 눈을 뜰 수 없을 정 도로 증세가 악화되고 치료에 전혀 반응을 보이지 않았다는 점과 이전의 투병 기록을 볼 때 효종에게는 염증성 질환을 악 화시킬 만한 다른 전신 질환이 있음을 추측할 수 있다. ${ }^{5)}$ 효종 7년 4월 20일 승정원일기의 기사를 보면 효종은 煩渴(번갈) 의 증상을 호소하는데(藥房再啓曰, 郎因醫官, 伏聞聖候, 向未 快復。且有煩渴困睡之患) 이는 가슴이 답답하여 입이 마르고 갈증이 나는 증상으로 일반적으로 당뇨병에 나타나는 증상 을 표현할 때 사용하는 표현이다. 이에 의관은 맥문동음(麥門

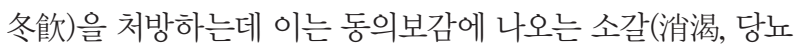
병)의 대표적인 치료제이다. ${ }^{19)}$ 또한 효종 9 년 1 월에는 약 20 일 간 팔 부위의 종기로 고생하였으며 ${ }^{20)}$ 사망하기 바로 몇 개월 전인 효종 9년 6월 10년 1월까지 약 6개월 동안은 족부에 발 생한 종기 증상으로 지속적으로 약물 복용 및 침 치료를 받 은 것으로 되어 있다(“주상의 발가락에 부기가 있어 침을 맞 았다.”). ${ }^{21,22)}$ 이처럼 효종 또한 세종, 세조 등 조선의 왕들의 가 족력이던 당뇨병 및 이와 관련된 합병증을 않고 있었다고 볼 수 있다. 또한 조선왕조실록 및 승정원일기에서 효종 10년에 집중적으로 거론되었던 병증이 종기 증세였던 것을 볼 때 ${ }^{5)}$ 효종은 사망 수 개월 전부터 당뇨병 및 이의 합병증인 당뇨병 성 피부궤양(족부궤양)을 않는 등 전신 상태가 매우 좋지 않 았음을 추측할 수 있다.

\section{침(鍼) 시술이 과다출혈을 유발할 수 있나?}

효종이 당뇨병 및 전이개낭종에 동반된 안면부감염 증세 가 있었다고 해도 조선왕조실록에 의하면 직접 사인은 침을 맞고 난 후에 발생한 과다출혈이다. 일개 범부도 아닌 지존인 국왕이 침을 맞고 과다출혈로 사망한다는 것이 매우 황당한 일이고 이는 현대 의학의 관점에서 볼 때도 명백한 의료 과 실에 해당한다. 그런데 침에 의해 사망에 이를 정도의 과다출 혈이 발생할 수 있을까, 하는 의문이 든다. 마침 수침을 한 신 가귀가 수전증을 않고 있었으며 지병으로 인해 집에서 머물 고 있다가 효종 사망 당일 급하게 입궐하여 침을 놓았다는 점에서 신가귀가 서인측의 사주를 받았다는 등의 의혹이 급 속히 펴져 나갔다. ${ }^{6,7)}$

조선왕조실록에서는 "피가 계속 그치지 않고 솟아 나왔는 데 이는 침이 혈락(血絡)을 범했기 때문이었다.”라고 기술하고
있다. 그럼 혈락은 무엇을 말하는 것일까? 효종이 침을 맞은 시간은 아침 수라를 들기 전이었고 사망한 시간은 사시(已時, 오전 9 11시)에서 오시(午時, 오전 11시 오후 1시) 사이였 다. ${ }^{23)}$ 조선의 왕은 일반적으로 오전 7시경에 아침 식사를 하 므로 침을 맞은 시간은 대략 7시 전후이고 사망한 시간은 오 전 11시경이므로 약 4 5시간 정도 출혈이 지속된 것으로 추 측할 수 있다. ${ }^{6)}$ 성인 남성이 과다출혈에 의해서 의식 소실 또 는 사망에 이르기까지는 전체 혈액량의 $40 \%$ 정도에 해당하 는 $2000 \mathrm{~mL}$ 의 혈액 소실이 필요하다. ${ }^{24)}$ 따라서 효종의 경우 시간당 약 400 500 mL 정도의 출혈이 발생한 것으로 볼 수 있다. 침을 놓은 부위는 전이개낭종에 의한 고름집 주변이므 로 귀 바로 앞쪽의 구레나룻 부위이다. 이 부분을 주행하는 혈관은 천측두동맥 및 정맥(superficial temporal artery/ vein)인데 지혈 등의 처치에도 불구하고 피가 그치지 않고 '솟 아' 나왔으며 시간당 $400 \mathrm{~mL}$ 이상의 출혈이 있던 것으로 보 아 천측두동맥이 손상을 받은 것으로 볼 수 있다.

그렇다면 주사기 바늘보다 가느다란 침으로 과다출혈을 유 발할 정도의 혈관 손상이 어떻게 가능했을까? 실록에 의하 면 효종이 종기 증상으로 침을 맞은 것은 사망 당일이 처음 이 아니다. 사망 3 일 전인 5월 1일에 의관 유후성이 처음으로 아침, 저녁으로 하루 두 번 침을 놓았으며(“약방이 들어가 진 찰하니, 부기(浮氣)가 점점 심하였다. 의관(醫官) 유후성(柳後 聖)이 아뢰기를, “독기(毒氣)가 안포(眼胞)에 모여있으니 의당 산침(散鍼)을 놓아서 배설시켜야 합니다.하니, 따랐다.” $)^{25)}$ 이 후 5월 3일에도 한 번 더 침을 맞았다(“상의 병이 위독하여 편전(便殿)에 나아갈 수 없었다. 약방이 대조전(大造殿)에 들 어가 진찰하였다. 상이 산침을 맞았다.”.). ${ }^{26)}$

침에 의한 천측두동맥 손상 가능성은 조선왕조실록에 쓰 여 있는 '산침(散鍼)'이란 단어로부터 실마리를 풀 수 있다. 일 반적인 침 시술은 경락상의 혈자리에 놓는 것인 반면 산침은 혈자리가 아니라 병소에 따라 임기응변식으로 아픈 곳을 따 라 찌르면서 피를 빼는 방식으로 침을 놓는 것이다. ${ }^{5,27)}$

동의보감에 따르면 우리나라에서 전통적으로 사용하는 침 에는 참침(鋔鍼), 원침(圓鍼), 적침(鍉鍼), 봉침(鋒鍼), 피침(鈹 鍼), 원리침(圓利鍼), 호침(毫鍼), 장침(長鍼), 대침(大鍼)의 구 침(九鍼)이 있다. ${ }^{28)}$ 우리가 일반적으로 침이라고 생각하는 얇 고 가느다란 형태의 것은 호침으로 굵기가 $0.20 \sim 0.25 \mathrm{~mm}$ 이 다. 반면 종기의 침파절개술, 즉 산침에 사용했던 침은 피침과 봉침으로, 현대에는 거의 사용하지 않는 침으로서 형태는 수 술용 blade와 유사하다(Fig. 1). ${ }^{29}$ 피침의 길이는 약 $120 \mathrm{~mm}$ (4촌)에 너비는 약 $7.5 \mathrm{~mm}$ (2푼 반)으로 형상은 칼을 닮아 검 침(劍鍼)이라고도 하며, 환부를 절개하고 옹종 등을 째어 고 름을 짜내는 데 사용하였다. 봉침의 길이는 약 $48 \mathrm{~mm}(1$ 촌 

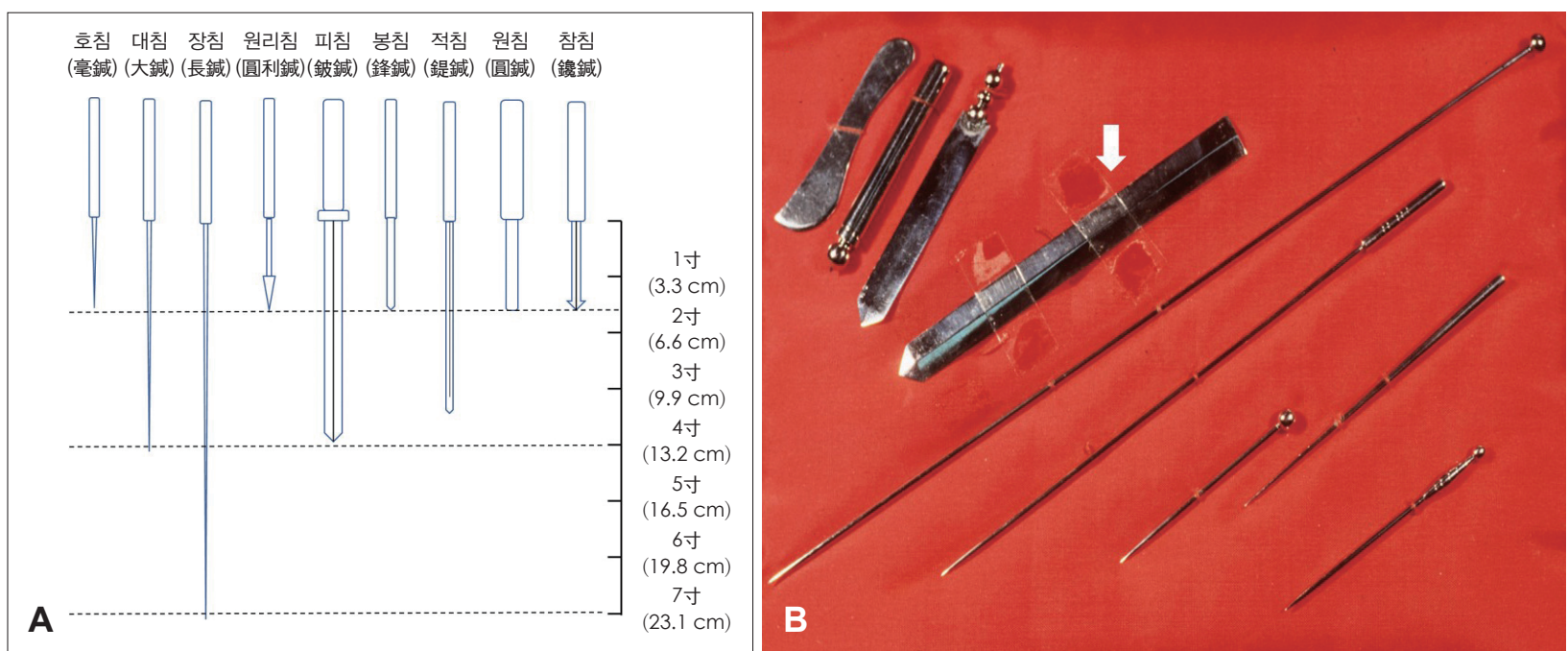

Fig. 1. 우리나라 전통 구침(九針). 아홉 종류 침의 모식도. 현재 한의학에서 가장 많이 사용하고 있는 것은 호침이며 배종에 주로 사용하던 침 은 피침과 봉침임(A) ${ }^{35)}$ 실제 사용되던 침. 가운데 칼 형태의 침이 피침임(B, arrow). Adapted from 백과사전 콘텐츠, with permission of The Academy of Korean Studies. ${ }^{29}$

6푼)으로 삼 면에 날이 서 있어서 일명 삼릉침(三稜鍼)이라 고도 하며, 주로 사혈에 사용한 침이다. ${ }^{28)}$

그렇다면 피침 또는 봉침을 사용한 침파절개술은 어떤 방 법으로 시행했을까? 우리나라는 예로부터 의식주 형태 및 부 실한 위생 상태 등으로 창양(瘡瘍) 질환이 많이 발생하였고 이를 치료하기 위한 치종의학(治腫醫學)이 유구한 전통을 가 지고 발전해왔으며 침파술과 같은 외과술도 활발히 시행되 었다. ${ }^{30)}$ 조선 중기에 이르러서는 종기 치료를 주로 다루는 우 리나라 최초의 외과전문서인 치종비방(治腫秘方)이 출판되었 고(명종 14년, 1559년) 종기 전문 치료 기관인 치종청(治腫廳) 도 설립이 되었다. 치종지남(治腫指南)은 조선 명종 때 치종 의로 활약하고 치종비방의 저자인 임언국(任彦國)의 제자들 이 임언국의 술기를 집대성한 책으로 ${ }^{30)}$ 치종지남의 배종도(背 腫圖)를 보면 배농을 하는 방법에 대해 자세히 설명이 되어 있는데 다음과 같다(Fig. 2). ${ }^{311}$ '침으로 찢을 때에는 네 방위를 정하고 깊이를 헤아린 후 우선 건방(乾方)을 찢어 손방(巽方) 에 이르게 하고 다음으로 간방(艮方)을 찢어 곤방(坤方)에 이 르게 하면, 침이 지나간 두 길이 '十'자 형태와 같아서 모두 비 스듬히 직각을 이루어 나쁜 피가 쉽게 흘러나온다. 혹은 찢 을 때에 간방(艮方)에서 시작해서 한가운데까지 찢고, 또 곤 방(坤方)에서 시작해서 한가운데까지 찢어서 서로 마주하게 하여 이어서 찢어지게 하면 침끝이 더 잘 들고 환자도 몹시 아파하지 않을 것이다. 침은 5 푼 $(15 \mathrm{~mm})$ 깊이까지 넣는다.'

즉 산침 또는 침파절개술은 사용 기구 및 방식이 현대 의학 에서 시행하는 절개 배농과 동일한 술식임을 알 수 있다. 즉 11 번 또는 12번 blade보다 더 큰 피침을 이용하여 $15 \mathrm{~mm}$ 깊 이로 귀의 앞쪽에 '十'자 형태로 절개를 했을 때 천측두동맥에
과다출혈을 유발하기에 충분한 손상이 발생할 가능성이 높 음을 알 수 있다.

\section{수전증을 않는 신가귀는 의도적으로 의료사고를 일으켰나?}

효종 독살설의 중요 핵심 쟁점 중 하나가 바로 효종 사망 시 시침을 한 어의 신가귀이다. 신가귀는 본래 무인 출신으로 침을 잘 놓아 인조 때 의관으로 임명된 인물로 아마도 칼에 익숙하고 전쟁터에서 다양한 부상병을 보면서 해부학적 지식 을 쌓았기 때문에 산침을 잘 놓았던 것으로 생각된다.

신가귀는 오래 않고 있던 질환으로 집에 머물고 있다가 효 종의 상태가 위중하자 사망 당일에야 입궐하였다. 산침을 놓 는 문제를 가지고 어의 유후성은 반대를 했으나 신가귀는 산 침을 놓아야 한다고 주장했고 효종이 허락하여 산침을 직접 놓았다. 문제는 이때 신가귀가 수전증을 가지고 있었다는 것 이다. 즉 수전증을 않고 있는 어의가 감히 임금에게 시침을 한 것 자체가 효종의 급사에 논란을 일으켰다. ${ }^{7)}$ 신가귀의 수 전증은 정말로 큰 문제였던 것일까? 효종 사망 직후 6월 2일 에 사후 책임 문제를 논하는 자리에서 현종은 "신가귀의 작년 공로는 잊을 수가 없다."라고 하였으며, ${ }^{32)}$ 6월 4일에는 "가귀가 $(\cdots)$ 지난해 파종(破腫) 때도 병이 없으면서 역시 손은 떨었다. 그것은 선왕께서 통촉하신 바로서 그가 침을 잘 놓는다고 늘 말씀하셨으며, 그후 그가 병이 중하여 죽게 되었다는 소식을 듣고는 불쌍하고 애석히 여기시는 말씀을 누차 하셨다. 그날 도 그로 하여금 침을 잡게 한 것은 원래 그래서였던 것이다." 라고 언급한다. ${ }^{33)}$ 즉 효종은 사망 1 년 전에도 이미 수전증을 가지고 있는 신가귀로부터 여러 차례 산침을 맞아서 효과를 


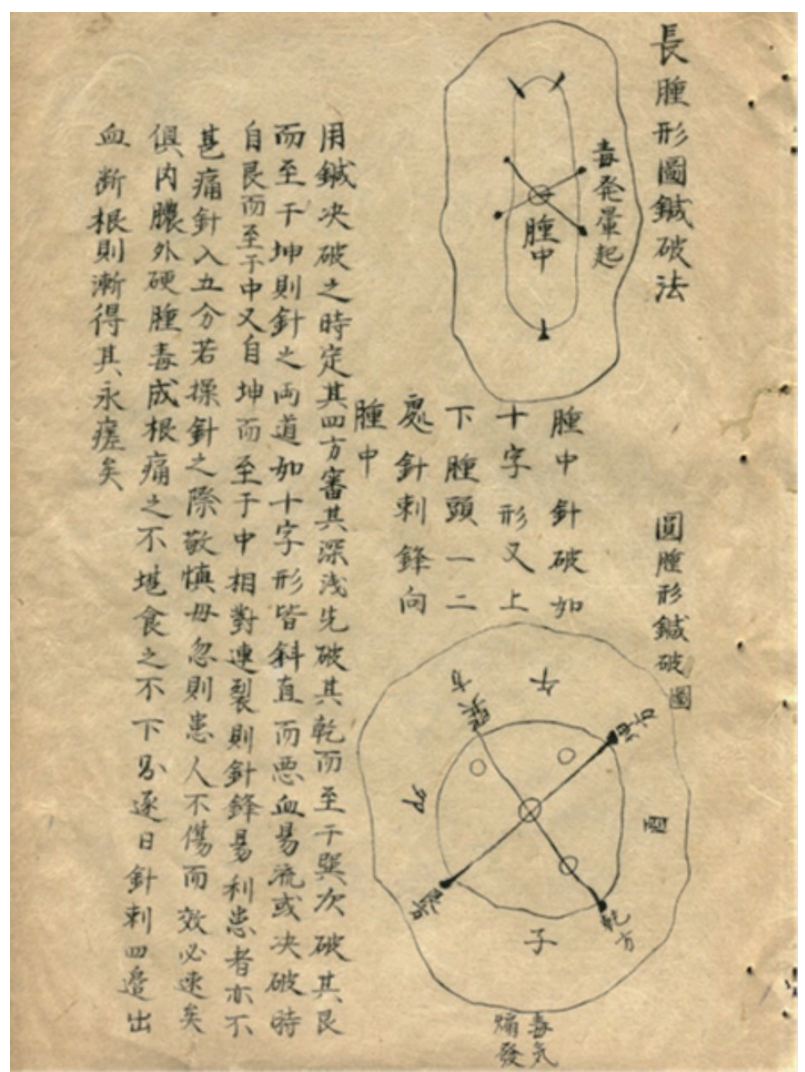

Fig. 2. 치종지남(治腫指南) 제 1 권 배종도(背腫圖) 중 장종형도침파법 (長腫形圖 鍼破法) 및 원종형침파도(圓腫形針破圖). 각각 긴 모양의 종기 및 둥근 모양의 종기를 침으로 찢는 방법을 설명한 도식. 종기 한가운데를 침으로'十'자 형태로 절개하는 방법으로 현대 의학의 절개 배농과 방식이 거의 유사하다. Adapted from Korea Institute of Oriental Medicine. ${ }^{31)}$

보았기 때문에 사망 당일에도 병석에 누워 있는 신가귀를 불 러 시침을 맡겼던 것으로 신가귀의 수전증은 실수를 유발할 만큼 큰 문제가 아니었으며 ${ }^{5}$ 항간의 의혹처럼 서인의 사주를 받은 신가귀가 일부러 입궐하여 의료사고를 고의로 낸 것도 아니라고 볼 수 있다.

그러면 유후성의 의견에 반대하여 무리하게 시행한 산침이 문제였던 것일까? 산침은 전술한 바와 같이 절개 배농에 해 당한다. 효종은 이미 5월 1일과 사망 전날인 5월 3일 저녁에 이미 해당 시술을 반대한 어의 유후성으로부터 두 차례 산침 을 맞았다. 따라서 신가귀가 놓은 산침은 세 번째에 해당한 다. 유후성은 사망 당일 시행한 세 번째 산침 시술은 반대했 는데 이는 본인도 이미 두 차례 시도를 했던 것으로 산침 자 체를 반대한 것보다는 이미 효종의 상태가 산침으로 해결될 수 없는 상태이므로 반대를 했던 것으로 생각된다. 또한 임금 의 병증에 대해 치료를 행함에 있어서 다양한 의견이 충돌하 는 것은 그 당시 매우 흔한 일이었는데 이는 한의학의 특성으 로, 임상에서 치료자에 따라 진단 및 치료 방법이 다양하게 도출되기 때문이다. ${ }^{27)}$ 이에 최상의 치료를 위해 효종 대에는
내의원(內醫院)에 의약동참청(議藥同參廳)을 설치하여 내의 원 소속 의관뿐 아니라 지방 각지의 의술이 높은 사람들을 모아서 일종의 다학제 진료를 시행하였으며 다양한 의견이 상충될 경우 효종의 경우처럼 임금이 최종 치료법을 선택하 기도 하였다. ${ }^{34)}$ 또한 정확한 시침(施鍼)을 위하여 점혈(點穴) 하는 의관과 실제 침을 놓는 의관을 달리 함을 원칙으로 하 였으며, 동일인이 점혈과 침을 놓는 경우 다른 의관들의 확인 을 받고 부정확할 경우에는 다른 의관이 다시 점혈을 하도록 했다. ${ }^{27)}$ 이러한 점들을 고려해 볼 때 신가귀가 효종 살해의 목적을 가지고 고의적으로 산침을 놓았다고는 보기 어렵다. 신가귀의 실수는 해부학에 대한 정확한 지식이 없는 상태에 서 일반 종기와 동일하게 생각하고 안면부에 절개 배농을 한 것으로 보는 것이 타당할 것이다.

\section{고 찰}

조선왕조실록 및 승정원일기의 내용과 참고 문헌을 고찰해 볼 때 효종의 선행 사인은 당뇨병, 중간 선행 사인은 감염된 전이개누공 및 이에 속발한 안면부 세포염, 직접 사인은 외상 성 혈관 손상으로 볼 수 있다. 물론 이 추론 또한 망자에 대 한 직접적 부검이 없는 상황에서 의학적 기록도 아닌 역사학 적 기록물만을 가지고 분석한 것인 만큼 독살설처럼 설득력 이 떨어지는 것일 수 있다. 다만 우리 민족이 남긴 위대한 기 록물인 조선왕조실록과 승정원일기를 통하여 후세의 한 임 상 의사가 의학적 추론에 따라서 400여 년 전 선조의 죽음에 대한 의문을 조금이나마 추적 가능했다는 점에서 의미가 있 다고 생각한다. 향후 이 연구를 통해 한의학에 머물고 있는 우리나라의 역사적 인물의 질병 및 사망 원인에 대한 연구가 현대 의학적 관점에서도 더욱 활발한 고찰이 이루어지길 기 대한다.

\section{Acknowledgments}

None.

\section{ORCID}

Han Su Kim

https://orcid.org/0000-0003-2239-0225

\section{REFERENCES}

1) terms.naver.com [homepage on the Internet]. 조선왕조실록. Seoungnam: NAVER [cited 2019 Feb 6]. Available from: URL: https://terms.naver. com/entry.nhn?docId $=548864 \&$ cid $=46622 \&$ categoryId $=46622$.

2) terms.naver.com [homepage on the Internet]. 승정원일기. Seoungnam: NAVER [cited 2019 Feb 6]. Available from: URL: htps://terms.naver. com/entry.nhn?docId $=795097 \&$ cid $=46622 \&$ categoryId $=46622$.

3) terms.naver.com [homepage on the Internet]. 효종. Seoungnam: NAVER [cited 2019 Feb 6]. Available from: URL: https://terms.naver.com/ entry.nhn?docId=1156058\&cid=40942\& categoryId=33383.

4) terms.naver.com [homepage on the Internet]. 소현세자. Seoungnam: 
NAVER [cited 2019 Feb 6]. Available from: URL: https://terms.naver. com/entry.nhn?docId $=1114259 \&$ cid $=40942 \&$ categoryId $=33383$.

5) Kim H. The study on disease \& death of HyoJong(孝宗) in ChoSun dynasty. Korean J Med Hist 2004;17(2):129-44.

6) 고대원, 김동율, 나향미, 박주영, 방성혜, 서창용, et al. 무지에서 비롯된 조선 최악의 의료사고. In: 박희연, editor. 역사 선생님도 가르쳐주지 않는 조선왕조 건강실록. 1st ed. Seoul: Trojan Horse;2017. p24-33.

7) 이덕일. 사라진 북벌의 꿈. 조선왕독살사건 2. 1st ed. Paju: Dasan Books;2008. p35-9.

8) sillok.history.go.kr [homepage on the Internet]. 효종실록 21권. Gwacheon: National Institute of Korean History [cited 2019 Feb 7]. Available from: URL: http://sillok.history.go.kr/search/ inspectionMonthList.do.

9) sillok.history.go.kr [homepage on the Internet]. 효종실록 21권, 효종 10 년 4월 27일 정사 1번 째 기사. Gwacheon: National Institute of Korean History [cited 2019 Feb 7]. Available from: URL: http:// sillok.history.go.kr/id/kqa_11004027_001.

10) sjw.history.go.kr [homepage on the Internet]. 승정원일기 156책 (탈초본 8책), 효종 10년 4월 27일 정사 2/6 기사. Gwacheon: National Institute of Korean History [cited 2019 Feb 7]. Available from: URL: http://sjw.history.go.kr/id/SJW-B10040270-00200.

11) hanja.dict.naver.com [homepage on the Internet]. 瘦. Seoungnam: NAVER [cited 2019 Feb 7]. Available from: URL: https://hanja. dict.naver.com/search?query $=\% \mathrm{E} 7 \% 99 \% \mathrm{~A} 4$.

12) sjw.history.go.kr [homepage on the Internet]. 142책 (탈초본 7책) 효종 7년 10월 7일 신사 2/7 기사. Gwacheon: National Institute of Korean History [cited 2019 Feb 7]. Available from: URL: http://sjw.history. go.kr/id/SJW-B07100080-00500.

13) sjw.history.go.kr [homepage on the Internet]. 승정원일기 142책 (탈초본 7책) 효종 7년 10월 8일 임오 5/16 기사. Gwacheon: National Institute of Korean History [cited 2019 Feb 7]. Available from: URL: http://sjw.history.go.kr/id/SJW-B07100080-00500

14) sjw.history.go.kr [homepage on the Internet]. 승정원일기 142책 (탈초본 7책) 효종 7년 10월 14일 무자 3/15 기사. Gwacheon: National Institute of Korean History [cited 2019 Feb 7]. Available from: URL: http://sjw.history.go.kr/id/SJW-B07100140-00300.

15) 정기태, 이상혁. 효종대왕실록 제 21 권. $1 \mathrm{st}$ ed. 서울: 민족문화추진회; 1990. p.336-8, p.339-49.

16) encykorea.aks.ac.kr [homepage on the Internet]. 시약청(侍藥廳). Seongnam: The Academy of Korean Studies [cited 2019 Apr 5]. Available from: URL: http://encykorea.aks.ac.kr/Contents/ Index?contents id=E0032399.

17) sillok.history.go.kr [homepage on the Internet]. 효종실록 21 권, 효종 10년 4월 28일 무오 1번 째기사. Gwacheon: National Institute of Korean History [cited 2019 Feb 7]. Available from: URL: http:// sillok.history.go.kr/id/kqa_11004028_001.

18) mjmedi.com [homepage on the Internet]. 숳ㄹㅇㅘ 한의학, 그리고 우리. Seoul: The Minjok Medicine News [cited 2010 Sep 4]. Available from: URL: http://www.mjmedi.com/news/articleView. html?idxno=19721.

19) Kang DH. Observations of King Hyojong's medical archives through 『Seungjeongwonilgi」 [dissertation]. Seoul: Kyung Hee University; 2010. p.21.

20) sillok.history.go.kr [homepage on the Internet]. 효종실록 20권, 효종 9년 6월 1일 정묘 1번째 기사. Gwacheon: National Institute of Korean
History [cited 2019 Feb 9]. Available from: URL: http://sillok. history.go.kr/id/kqa_10906001_001.

21) sjw.history.go.kr [homepage on the Internet]. 승정원일기 154책 (탈초본 8책) 효종 10년 1월 10일 임인 8/19 기사. Gwacheon: National Institute of Korean History [cited 2019 Feb 8]. Available from: URL: http://sjw.history.go.kr/id/SJW-B10010100-00800.

22) sillok.history.go.kr [homepage on the Internet]. 효종실록, 21 권, 효종 10년 1월 9일 신축 1번째기사. Gwacheon: National Institute of Korean History [cited 2019 Feb 8]. Available from: URL: http://sillok. history.go.kr/id/kqa_11001009_001.

23) sillok.history.go.kr [homepage on the Internet]. 효종실록 21권, 효종 10 년 5월 4일 갑자 1 번째기사. Gwacheon: National Institute of Korean History [cited 2019 Feb 8]. Available from: URL: http://sillok. history.go.kr/id/kqa 11005004001.

24) Gutierrez G, Reines HD, Wulf-Gutierrez ME. Clinical review: Hemorrhagic shock. Crit Care 2004;8(5):373-81.

25) sillok.history.go.kr [homepage on the Internet]. 효종실록 21권, 효종 10년 5월 1일 신유 2번째기사. Gwacheon: National Institute of Korean History [cited 2019 Feb 8]. Available from: URL: http://sillok. history.go.kr/id/kqa_11005001_002.

26) sillok.history.go.kr [homepage on the Internet]. 효종실록 21권, 효종 10 년 5월 3일 계해 2번째기사. Gwacheon: National Institute of Korean History [cited 2019 Feb 8]. Available from: URL: http://sillok. history.go.kr/id/kqa_11005003_002.

27) Hong SY. A study of the clinical records in Seungjeongwon Ilgi [dissertation]. Seoul: Kyung Hee University;2009.

28) terms.naver.com [homepage on the Internet]. 침의 종류와 방법. Seoungnam: NAVER [cited 2019 Jul 19]. Available from: URL: https://terms.naver.com/entry.nhn?docId=1223539\&cid=40942\&ca tegoryId $=32746$.

29) mm.aks.ac.kr [homepage on the Internet]. 구침. Seongnam: The Academy of Korean Studies [cited 2019 Jul 29]. Available from: URL: https://mm.aks.ac.kr/catalog/catalogList.aspx?SearchWord= $\% \mathrm{EA} \% \mathrm{~B} 5 \% \mathrm{AC} \% \mathrm{EC} \% \mathrm{~B} 9 \% \mathrm{~A} 8 \&$ SearchType $=\mathrm{TITLE}$.

30) 서지연. 임언국의 치종의학 연구 [dissertation]. Seoul: Kyung Hee University;2008. p.16.

31) mediclassics.kr [homepage on the Internet]. 치종지남 治腫指南. Daejeon: Korea Institute of Oriental Medicine [cited 2019 Aug 1]. Available from: URL: https://mediclassics.kr/books/85/volume/1.

32) sillok.history.go.kr [homepage on the Internet]. 현종실록 1권, 현종 즉위년 6월 2일 신묘 2번째기사. Gwacheon: National Institute of Korean History [cited 2019 Feb 8]. Available from: URL: http:// sillok.history.go.kr/id/kra_10006002_002.

33) sillok.history.go.kr [homepage on the Internet]. 현종실록 1권, 현종 즉위년 6월 4일 계사 3 번째기사. Gwacheon: National Institute of Korean History [cited 2019 Feb 8]. Available from: URL: http:// sillok.history.go.kr/id/kra 10006004003.

34) Yi KK. A study of uiyakdongcham in the Late of Chosun dynasty. The Choson Dynasty History Association 2001;19(12):119-45.

35) itmonline.org [homepage on the Internet]. Bleeding Peripheral points: An acupuncture technique. Portland, OR: The Institute for Traditional Medicine and Preventive Health Care, Inc. [cited 2019 Apr 5]. Available from: URL: http://www.itmonline.org/arts/ bleeding.htm. 